\title{
Achalasia of the cardia in elderly patients
}

\author{
M. R. Lock \\ F.R.C.S.
}

\author{
HaRold ELLIS \\ D.M., M.Ch., F.R.C.S.
}

\begin{abstract}
Summary
Achalasia of the cardia frequently presents as dysphagia in middle age. In the elderly, dysphagia is usually due to a neoplasm of the oesophagus or cardia. The authors have been interested to see five patients over the age of 70 presenting with oesophageal symptoms due to achalasia which is uncommon in this age group and may be mistaken for neoplastic disease.
\end{abstract}

\section{Case reports (see Table 1) \\ Case 1}

A diagnosis of achalasia had been made two years previously and subsequently this 85 -year-old woman had been eating only a semi-solid diet. She presented to the surgical clinic with increasing difficulty of swallowing and at the time of admission was vomiting and had complete dysphagia. Clinically she was anaemic and severely dehydrated; a barium swallow showed gross mega-oesophagus (Fig. 1). Following intravenous fluid therapy and a Heller's operation by the abdominal approach she made a rapid recovery. She now has returned to running her own business.

\section{Case 2}

A year previously a barium swallow had demonstrated achalasia, but the patient had not been referred for surgery because she was considered too old at 88 years of age. At the time of admission she had been vomiting copiously for 7 weeks and had been unable to eat solids for many days; a further barium swallow showed an increased megaoesophagus and a small right-sided aspiration pneumonia. Following intensive physiotherapy and correction of her fluid balance, an abdominal Heller's operation was performed. Postoperatively her chest infection worsened and failed to respond to physiotherapy and antibiotics. At post-mortem a large abscess was found at the right lung base.

\section{Case 3}

An 83-year-old woman presented with a 3-month history of vomiting, eructation, anorexia and a tight feeling at the lower end of the sternum. A barium swallow showed marked delay of contrast at the lower end of the oesophagus with much retained food residue. She underwent transthoracic Hellers' operation and was discharged home 2 weeks later.

TABLE 1. Clinical details of patients

\begin{tabular}{|c|c|c|c|c|c|c|}
\hline $\begin{array}{l}\text { Case } \\
\text { no. }\end{array}$ & $\begin{array}{l}\text { Age } \\
\text { (years) }\end{array}$ & Sex & History & $\begin{array}{l}\text { Previous treatment } \\
\text { and outcome }\end{array}$ & Operation & Operative result \\
\hline 1 & 85 & $\mathrm{~F}$ & $\begin{array}{l}2 \text { years' retrosternal } \\
\text { discomfort. }\end{array}$ & $\begin{array}{l}\text { Fluid diet } 2 \text { years. } \\
\text { Anaemic and grossly } \\
\text { dehydrated. }\end{array}$ & $\begin{array}{l}\text { Abdominal } \\
\text { Heller }\end{array}$ & Good \\
\hline 2 & 88 & $\mathrm{~F}$ & $\begin{array}{l}2 \text { months' vomiting; } \\
\text { epigastric pain. }\end{array}$ & - & $\begin{array}{l}\text { Abdominal } \\
\text { Heller. }\end{array}$ & $\begin{array}{l}\text { Died with pulmonary abscess. } \\
\text { Pre-operative aspiration pneumonia. }\end{array}$ \\
\hline 3 & 83 & $F$ & $\begin{array}{l}3 \text { months' vomiting } \\
\text { retrosternal } \\
\text { discomfort. }\end{array}$ & - & $\begin{array}{l}\text { Transthoracic } \\
\text { Heller. }\end{array}$ & $\begin{array}{l}\text { Good. Died of intercurrent disease } 8 \\
\text { months later. }\end{array}$ \\
\hline 4 & 73 & $\mathbf{M}$ & $\begin{array}{l}17 \text { years' increasing } \\
\text { dysphagia. }\end{array}$ & $\begin{array}{l}\text { Self-bouginage } \\
15 \text { years. }\end{array}$ & $\begin{array}{l}\text { Transthoracic } \\
\text { Heller. }\end{array}$ & Good \\
\hline 5 & 81 & $\mathbf{M}$ & $\begin{array}{l}7 \text { months' regurgi- } \\
\text { tation. }\end{array}$ & $\begin{array}{c}\text { Refused dilatation } \\
\text { because of age. }\end{array}$ & $\begin{array}{l}\text { Abdominal } \\
\text { Heller. }\end{array}$ & Good (stricture dilated 1 year later). \\
\hline
\end{tabular}




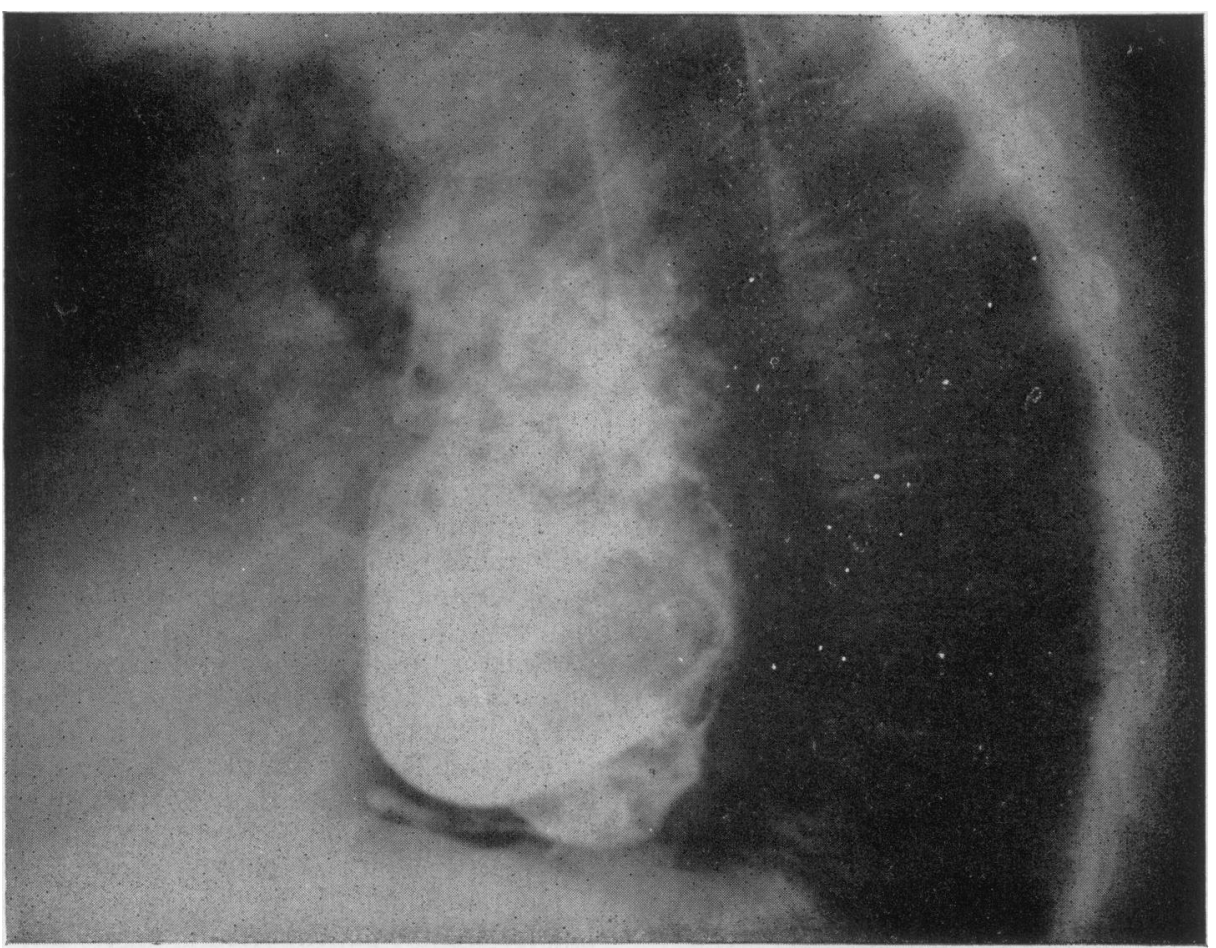

Fig. 1. Barium swallow. Lateral view showing grossly dilated oesophagus and contained food debris.

\section{Case 4}

This man had been advised at the age of 56 years to perform self-bouginage for his achalasia, and he had done this conscientiously for 17 years. At the age of 73 years he presented with worsening symptoms of dysphagia and a loss of more than $10 \mathrm{~kg}$ in weight. Following a transthoracic Heller's operation he had no further symptoms and remains well 12 years later.

\section{Case 5}

One year previously this 81-year-old man's condition had been correctly diagnosed. He had not even been referred for oesophageal dilatation because he was considered to be too old. When seen by the authors he was in good general health apart from an irondeficient anaemia. Following an abdominal Heller's procedure his symptoms were relieved. Nearly one year later a benign stricture of the lower oesophagus was dilated on one occasion and 3 years after dilatation he remains well with no further symptoms.

\section{Discussion}

Achalasia of the cardia is a condition in which there is a failure of relaxation of the sphincter at the lower end of the oesophagus. Manometric and radiological studies show that in normal people the sphincter relaxes $1 \cdot 5-2 \cdot 5$ seconds after swallowing (Ingelfinger, 1958). This relaxation depends upon the vagal and myenteric integrity within the oesophageal wall. Normally, a contraction passes down the oesophagus and ends with relaxation of a previously contracted lower sphincter. In achalasia similar studies show that there is only non-propulsive motor activity in the body of the gullet. The lower oesophageal sphincter has a higher resting pressure than normal, and it fails to relax in response to swallowing. Furthermore the sphincter contracts earlier than normal and this also impairs the nonpropulsive effect of the condition (Vantrappen et al., 1963).

The lesion of achalasia involves the myenteric plexus. The cause of the degeneration of the plexus is unknown. A similar lesion is present in Chagas' disease, where the myenteric plexus is damaged by neurotoxin liberated from the parasite Trypanosoma cruzi (Avery Jones, Gummer and Lennard-Jones, 1963). The pathological changes in achalasia are mainly in the upper and middle oesophagus, which is dilated and may also be lengthened and tortuous; 


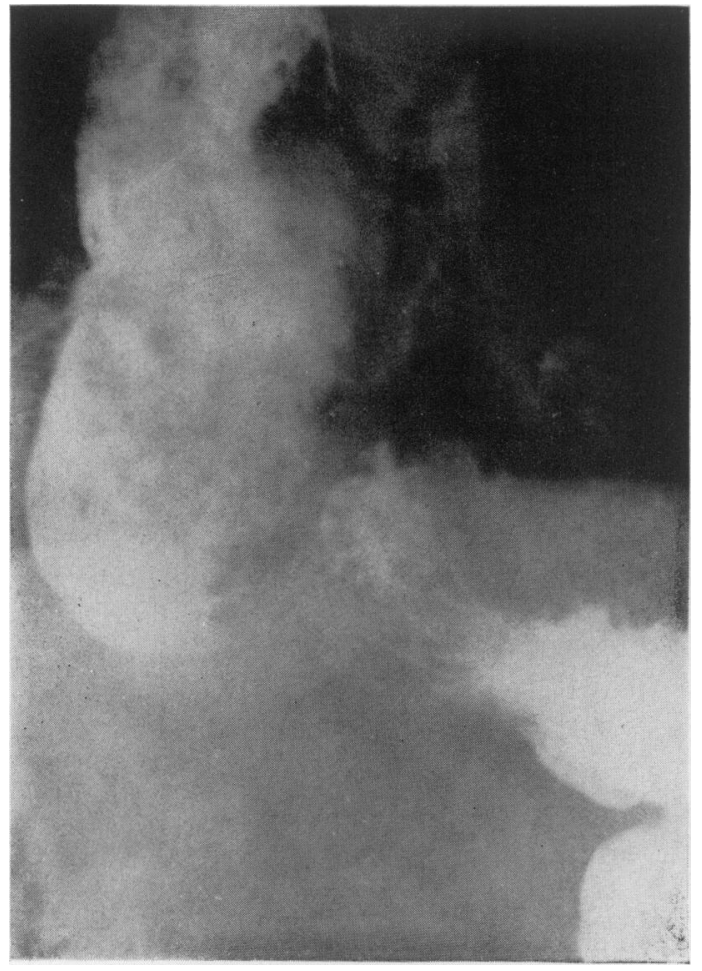

FIG. 2. Barium swallow. Dilated oesophagus with narrowed lower segment.

the extreme lower end of the oesophagus is narrow (Fig. 2). Inflammation of the oesophageal wall usually occurs because of retained food debris. Carcinoma of the oesophagus is said to occur in up to $25 \%$ of advanced cases (Adams et al., 1961).

Clinically, achalasia may present with a choking feeling on swallowing, a sensation of regurgitation or with severe chest pain. This classically does not have the sour taste of vomit, and is worse with fluids than solids and when lying down. There may be hiccough, weight loss or a concomitant arthritis, which is related to the pneumonitis (Adams et al., 1961). A carcinoma developing within the dilated oesophagus is suggested by pain, blood stained vomit or an offensive smell and taste. Achalasia typically commences with symptoms of pain and indigestion. These may lessen as the oesophageal musculature becomes decompensated and the oesophagus becomes increasingly dilated and tortuous. At this stage there may be few symptoms for many years but eventually there is a deterioration in the general health when anaemia, cachexia, vitamin deficiency, aspiration pneumonitis or carcinoma supervene.

Achalasia occurs most commonly between the ages of 40 and 60 years and less often at the extremes of life. Dysphagia presenting in an elderly patient with no previous history of dyspepsia or surgery is usually considered to be malignant. The finding of five patients in this age group with benign oesophageal disease suggests that this assumption is not always justified. A full series of barium swallow and endoscopy investigations should be performed in all patients of this age who are fit to undergo them in order to exclude the possibility of a benign condition being mistaken for neoplasia. Provided that the patient is in good general health, operation for this benign condition will usually be successful and often has an excellent chance of cure. The alternatives are either to submit the elderly patient to frequent dilatation with all the attendant risks of to do nothing, leaving the patient often in misery and to die of cachexia, carcinoma or pulmonary infection. Heller's operation by the abdominal approach causes little constitutional disturbance. If followed by immediate mobilization and a rapid return to oral feeding the chances of a permanent cure are good and the patient can pass the rest of his days with the comfort and satisfaction of normal deglutition.

\section{References}

Adams, C.W.M., Brain, R.H.F., Ellis, F.G., Kauntze, R. \& Trounce, J.R. (1961) Achalasia of the cardia. Guy's Hospital Reports, 110, 191.

Avery-Jones, F., Gummer, J.W.P. \& LenNard-Jones, J.E. (1963) Clinical Gastroenterology 2nd edn, p. 107. Blackwell Scientific Publications, Oxford.

INGELFINGER, F.J. (1958) Esophageal mobility. Physiological Reviews, 38, 533.

Vantrappen, G., Van Goidsenhoven, G.E., Verbeke, S., Berghe, G.V.D. \& VANDEnbroucke, J. (1963) Manometric studies in achalasia of the cardia. Gastroenterology, $45,317$. 